\title{
Six-month follow-up of laser in-situ keratomileusis for myopia
}

Istiantoro, Tjahjono D. Gondhowihardjo, Johan Hutauruk

\begin{abstract}
Abstrak
Penelitian retrospektif untuk menilai hasil refraksi dari laser in-situ keratomileusis (Lasik) menggunakan excimer laser untuk menentukan ketepatan, prediktabilitas, keamanan dan stabilitas koreksi miopia. Lasik dilakukan pada 475 mata pada 302 penderita miopia dengan ekwivalen sferis (ES) dari -0.50 sampai -27 dioptri (D). Dibagi dalam grup $A$ (ES kurang dari $-6.00 D), B(S E-6.00$ sampai -11.99) dan C (ES -12.00 D atau lebih). Pengamatan dilakukan sampai 6 bulan. Hasil: pada semua grup hanya 122 mata mendapat pengamatan 6 bulan. Rerata pra-bedah ES $-8.45 \mathrm{D} \pm 4.66$ dan rerata pra-bedah silinder $-1.10 \mathrm{D} \pm 1.07$ (dari plano sampai $-6.00 \mathrm{D}$ ). Pada 6 bulan, hasil koreksi dalam kisaran $2.00 \mathrm{D}$ dari koreksi seharusnya tercapai pada $95.6 \%$ grup A, $97.7 \%$ grup B dan $78.1 \%$ grup C. Rerata regesi kurang dari $1.00 \mathrm{D}$ terdapat pada semua grup pada pengamatan 6 bulan. Komplikasi terdapat pada 29 mata $(6 \%)$ untuk seluruh grup. Kesimpulan: Lasik sangat efektif dan tepat untuk koreksi miopia rendah dan sedang. Untuk miopia tinggi $(>-12.00 \mathrm{D})$ efektivitas dan prediktabilitas cukup baik. Stabilitas refraksi sampai 6 bulan tampaknya baik, namun diperlukan pengamatan lebih lama lagi.
\end{abstract}

\begin{abstract}
Retrospective study to evaluate the refractive results of laser in-situ keratomileusis (LASIK) using excimer laser performed on myopic eyes; to determine the accuracy, predictability, safety and stability of LASIK as a treatment to correct myopia. LASIK was performed on 475 eyes of 302 consecutive patients with preoperative spherical equivalent refraction (SE) ranging from -0.50 to -27.00 diopters $(D)$. The eyes were assigned to one of three groups: Group A (SE less than $-6.00 \mathrm{D}), \mathrm{B}(\mathrm{SE}-6.00$ to $-11.99 \mathrm{D})$, or C (SE -12.00 $D$ or higher). Follow-up time was up to 6 months. Results: For all groups, follow-up was obtained for 122 eyes at 6 months. The mean preoperative spherical equivalent was $-8.45 \mathrm{D} 4.66$ [SD], and the mean preoperative cylinder was $-1.10 D \pm 1.07$ [SD] (range: plano to -6.00D). At 6 months, $95.6 \%$ of the eyes in Group A, 97.7\% in Group B, and 78.1\% in Group C were within $2.00 \mathrm{D}$ of intended correction. The mean regression at 6 months was less than $1.00 \mathrm{D}$ in all groups. Complications were observed in 29 eyes (6\%) of all groups. Conclusion: LASIK was found to be very effective and predictable in the correction of low and moderate myopia. For high myopia (>-12.00 D), the effectiveness and predictability of LASIK were fairly good. Results after 6 months tend to suggest the stability of postoperative refraction, but long-term follow-up will be required to make further conclusions.
\end{abstract}

Keywords: Lasik, excimer laser, corneal flap technique

The use of ultraviolet 193-nm excimer laser for corneal surgery has been suggested in several studies since the first study by Trokel et al ${ }^{1}$ in 1983 . Radiation emitted by the argon fluoride excimer laser has demonstrated a unique ability to ablate corneal tissue with submicrometer accuracy, leaving minimal residual tissue damage. ${ }^{2,3}$ Its application on human eyes was first published in $1989^{4}$ with a good result. As the technology known as photorefractive keratectomy (PRK) has evolved, there are 2 major problems encountered. The first problem is subepithelial haze in the visual axis,

Department of Ophthalmology, Faculty of Medicine, University of Indonesia, Jakarta, Indonesia and the second is the predictability and stability of the refractive results in high myopia.

Since PRK did not prove its safety, effectiveness, and predictability in myopia higher than $6.00 \mathrm{D} .^{5,6} \mathrm{Pal}-$ likaris et al suggested the corneal flap technique for "laser in situ keratomileusis" (LASIK) for high levels of myopia. LASIK is a refractive surgery technique that uses microkeratome to raise a corneal flap and followed by an excimer laser to ablate the stromal bed. 8,9

This study analyzes the refractive results of 475 consecutive LASIK procedures performed on normal, sighted myopic eyes; to determine its efficacy and predictability as a treatment to correct myopia. 


\section{METHODS}

\section{Patients}

One hundred twenty-nine males and 173 females (475 eyes) underwent LASIK procedures for the correction of myopia. Eyes were treated between March 25, 1997 and September 27, 1997. Their age ranged from 17 to 62 years (mean: 30.5 years), and the preoperative refraction (spherical equivalent) ranged from -0.50 to -27.00 diopters (D) (mean \pm standard deviation, -8.45 $\pm 4.66 \mathrm{D})$. The mean preoperative cylinder was -1.10 $\pm 1.07 \mathrm{D}$ (range, 0.00 to $-6.00 \mathrm{D}$ ).

Stability of refraction was documented by previous clinical records, and any patient exhibiting a refractive change of at least $0.50 \mathrm{D}$ during the last year was excluded. Exclusion criteria for LASIK procedures included keratoconus, flat cornea, dry eye, or other corneal inflammatory diseases. No subject had any signs of systemic disease.

The eyes were divided into three groups based on the amount of preoperative spherical equivalent (SE). Group A included 134 eyes with SE less than -6.00 D. Group B included 219 eyes with SE between -6.00 D and-11.99 D; and Group C included 122 eyes with SE-12.00 D or higher. Informed consent was obtained from all patients after a detailed description of LASIK procedures and a thorough review of the procedure's known risk.

\section{Preoperative examination}

Preoperative evaluations were performed on all patients included external, slit-lamp, and dilated fundus examination. Visual acuity (Snellen) was evaluated without correction and with manifest refraction. Other measurements taken were keratometry and ultrasonic pachymetry. Topographical analysis of the cornea was attempted on each patient. If the pupil was dilated, 2 (two) drops of pilocarpine $2 \%$ were used to constrict the pupil making centration of the suction ring easier.

\section{Surgical procedure}

The ocular surface was anesthetized with a total of 3 drops lidocaine hydrochloride $20 \mathrm{mg} / \mathrm{ml}$ (Xylocaine ${ }^{\circledR}$ $2 \%$ ) at 30, 15 and 5 minutes before surgery. One drop of Chloramphenicol $0.5 \%$ (Cendo Fenicol ${ }^{\circledR}$ ) was given every 5 minutes for 15 minutes before surgery. The eyelids were separated with an eyelid speculum and the eye was cleaned with normal saline.
A landmark was made on the cornea with gentian violet using a corneal marker with 3.0 and $10.5 \mathrm{~mm}$ rings linked by a pararadial line. The automated corneal shaper, automated microkeratome (Chiron Vision) and suction ring were assembled by the surgeon with a 160 $\mu \mathrm{m}$ or $130 \mu \mathrm{m}$ plate, depended on the corneal thickness and the degree of intended ablation. Then a suction ring was applied, centered on the previous marks. Intraocular pressure (IOP) was verified to be greater than $65 \mathrm{~mm} \mathrm{Hg}$ with Barraquer tonometer. The optical zone of the flap cut was measured to be greater than $7.2 \mathrm{~mm}$ using a $7.2 \mathrm{~mm}$ applanation lens.

The corneal surface was irrigated with balance salt solution and the microkeratome head was placed in position to produce a corneal flap. After the corneal flap was formed, the microkeratome and its suction ring were removed and the flap was reflected nasally. Both the internal side of the flap and the corneal bed were irrigated with normal saline to remove epithelial waste. The exposed stromal bed was then ready for laser ablation.

An ArF excimer laser system (Chiron 217) was used to correct refractive errors. The excimer laser produced 193-nm ultraviolet light with a fluence of $160 \mathrm{~mJ} / \mathrm{cm} 2$ and a pulse rate of $5 \mathrm{~Hz}$.

The laser system's computer program was also used to record parameters such as patient identification and ablation depth, rate and diameter. The LASIK algorithm program was used with Maria Clara's modification (Table 1). After excimer laser ablation, the ablated bed was irrigated with balance salt solution. The corneal bed and the inner surface of the flap were dried with absorptive sponge, and the flap was realigned with the marks to its original position. Striae test was performed to determine that the flap was properly seated, by pressing gently at the edge of the recipient with closed tying forceps and watching for striae radiating up into the flap. At the end of surgery, Chloramphenicol $0.5 \%$ (Cendo-Fenicol ${ }^{\circledR}$, PT. Cendo Indonesia) eye drops were instilled into the eye. Eyes were protected with a clear shield after surgery.

Table 1. Maria Clara's modification of myopic normogram for LASIK

\begin{tabular}{cc}
\hline Spherical Equivalent (D) & Correction added (D) \\
\hline 0.00 to -2.00 & -0.25 \\
-2.50 to -4.00 & -0.50 \\
-4.25 to -6.00 & -0.75 \\
$>-6.00$ & -1.00 \\
\hline
\end{tabular}




\section{Postoperative examination}

Follow-up examinations were scheduled after surgery at the 1st day, 1 st week, and 1st, 3rd and 6th month respectively. In addition to visual acuity, refraction and slit lamp examination of the cornea, flap and anterior segment were performed at each visit. Corneal topography was only performed if visual acuity on the operated eyes were not better than the preoperative best corrected visual acuity. Chloramphenicol $0.5 \%$ (Cendo Fenicol ${ }^{\circledR}$ PT. Cendo Indonesia) eye drops were instilled three times a day for the first 7 days. Eyes were also randomly divided into two groups, treated with either corticosteroid or nonsteroidal anti-inflammatory drug (NSAID) eye drops. Patients were advised to avoid direct pressure to the eye for 12 weeks.

\section{RESULTS}

For all groups, mean preoperative uncorrected visual acuity (UCVA) was $0.05 \pm 0.09 \mathrm{D}$; mean preoperative spherical equivalent (SE) was $-8.45 \pm 4.66 \mathrm{D}$; and mean preoperative cylinder was $-1.10 \pm 1.07 \mathrm{D}$ (range, 0.00 to $-6.00 \mathrm{D}$ ). The number of eyes in the three groups (A, B and C) which was followed-up was shown in Table 2.

Table 3 summarizes the refractive results of each group. The postoperative predictability after 6 months in group A demonstrated that $79.1 \%$ of eyes were within $\pm 0.50 \mathrm{D}, 93.5 \%$ were within $\pm 1.00 \mathrm{D}$, and $95,6 \%$ were within $\pm 2.00 \mathrm{D}$. Attempted versus achieved correction at 6 months is shown in Figure 1.

Table 2. Patients characteristics

\begin{tabular}{|c|c|c|c|c|c|c|c|c|}
\hline \multirow{2}{*}{ Group } & \multirow[b]{2}{*}{$\mathrm{n}$} & \multicolumn{3}{|c|}{ Preoperative } & \multicolumn{4}{|c|}{ Number of eyes at follow-up } \\
\hline & & Mean UCVA & Mean spherical equivalent (D) & Mean cylinder (D) & I Day & $1 \mathrm{M}$ & $3 \mathrm{M}$ & $6 \mathrm{M}$ \\
\hline A & 134 & 0.106 & -3.04 & -0.69 & 134 & 113 & 87 & 46 \\
\hline B & 219 & 0.033 & -8.02 & -1.15 & 219 & 180 & 141 & 44 \\
\hline $\mathrm{C}$ & 122 & 0.017 & -14.76 & -1.57 & 122 & 104 & 81 & 32 \\
\hline Total & 475 & $0.05 \pm 0.09$ & $-8.45 \pm 4.66$ & $-1.10 \pm 1.07$ & 475 & 397 & 309 & 122 \\
\hline
\end{tabular}

$\mathrm{n}=$ Number of eyes, $\mathrm{M}=\operatorname{month}(\mathrm{s})$

Table 3. Refractive results

\begin{tabular}{|c|c|c|c|}
\hline \multirow{2}{*}{ Measurements } & \multirow{2}{*}{$\frac{\text { UCVA }}{\text { Mean } \pm S D}$} & \multirow{2}{*}{$\frac{\text { Spherical Equivalent (D) }}{\text { Mean } \pm \text { SD }}$} & \multirow{2}{*}{$\frac{\text { Spherical correction (D) }}{\text { Mean } \pm \text { SD }}$} \\
\hline & & & \\
\hline \multicolumn{4}{|c|}{ Group A $(<-6.00)^{*}$} \\
\hline Preoperative & $0.106 \pm 0.15$ & $-3.40 \pm 1.39$ & - \\
\hline 1 day & $0.677 \pm 0.27$ & $0.49 \pm 0.76$ & $3.91 \pm 1.75$ \\
\hline 1 month & $0.833 \pm 0.22$ & $0.33 \pm 0.74$ & $3.75 \pm 2.02$ \\
\hline 3 months & $0.867 \pm 0.20$ & $0.22 \pm 0.72$ & $3.60 \pm 2.08$ \\
\hline 6 months & $0.879 \pm 0.21$ & $0.19 \pm 0.73$ & $3.03 \pm 1.78$ \\
\hline \multicolumn{4}{|c|}{ Group B $(-6.00 \text { to }-11.59)^{*}$} \\
\hline Preoperative & $0.033 \pm 0.04$ & $-8.02 \pm 1.67$ & - \\
\hline 1 day & $0.582 \pm 0.24$ & $0.71 \pm 0.91$ & $8.68 \pm 2.07$ \\
\hline 1 month & $0.761 \pm 0.22$ & $0.11 \pm 0.72$ & $8.29 \pm 1.76$ \\
\hline 3 months & $0.783 \pm 0.23$ & $0.04 \pm 0.65$ & $8.11 \pm 1.75$ \\
\hline 6 months & $0.821 \pm 0.24$ & $-0.11 \pm 0.71$ & $7.93 \pm 1.42$ \\
\hline \multicolumn{4}{|c|}{ Group C (-12.00 or higher ${ }^{*}$} \\
\hline Preoperative & $0.017 \pm 0.01$ & $-14.76 \pm 3.04$ & - \\
\hline I day & $0.453 \pm 0.26$ & $-0.15 \pm 1.68$ & $14.52 \pm 2.82$ \\
\hline 1 month & $0.462 \pm 0.29$ & $-1.23 \pm 1.72$ & $13.25 \pm 2.67$ \\
\hline 3 months & $0.459 \pm 0.27$ & $-1.59 \pm 1.88$ & $12.53 \pm 2.45$ \\
\hline 6 months & $0.481 \pm 0.26$ & $-1.37 \pm 1.63$ & $12.24 \pm 2.75$ \\
\hline
\end{tabular}

* = Spherical equivalent in diopters (D) 


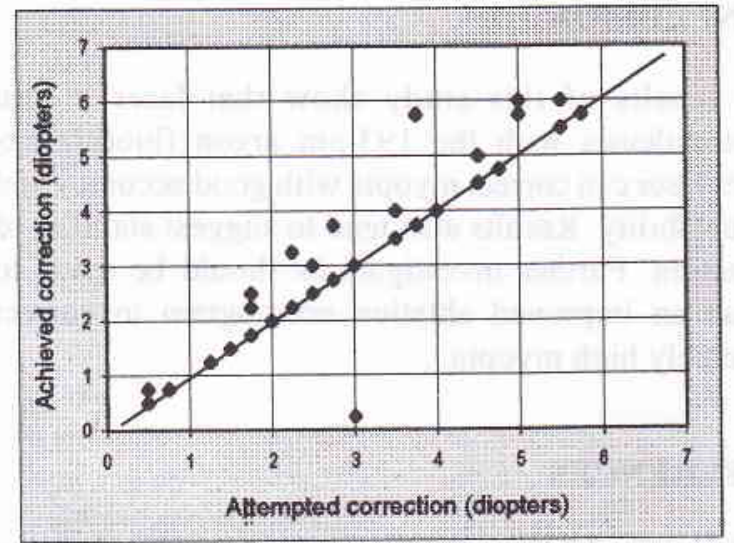

Figure 1. Group A: Attempted versus achieved correction after 6 months

In group $B$, the predictability after 6 months demonstrated that the SE of $81.8 \%$ of eyes were within $\pm 0.50 \mathrm{D}, 90.9 \%$ were within $\pm 1.00 \mathrm{D}$ and $97,7 \%$ were within $\pm 2.00 \mathrm{D}$. Figure 2 shows the attempted versus achieved correction of group B after 6 months. In group $C$ the postoperative predictability after 6 months demonstrated that the SE of $40.6 \%$ of eyes were within $0.50 \mathrm{D}, 53.1 \%$ were within $1.00 \mathrm{D}$, and $78.1 \%$ were within $2.00 \mathrm{D}$. Attempted versus achieved correction in group $\mathrm{C}$ after 6 months is shown in Figure 3.

Complications of LASIK procedures were found in $6 \%$ of eyes (29 of 475 eyes). These complications, which were associated with the creation of corneal flap, were as follows: epitheliopathy/erosion (16 eyes), interstitial debris ( 8 eyes), incomplete flap ( 2 eyes), free flap ( 2 eyes), and slipped flap (1 eye). In case of free flap and slipped flap, the flap was elevated, repositioned, and secured with 10/0 nylon sutures. Other complications were leave unmanaged.

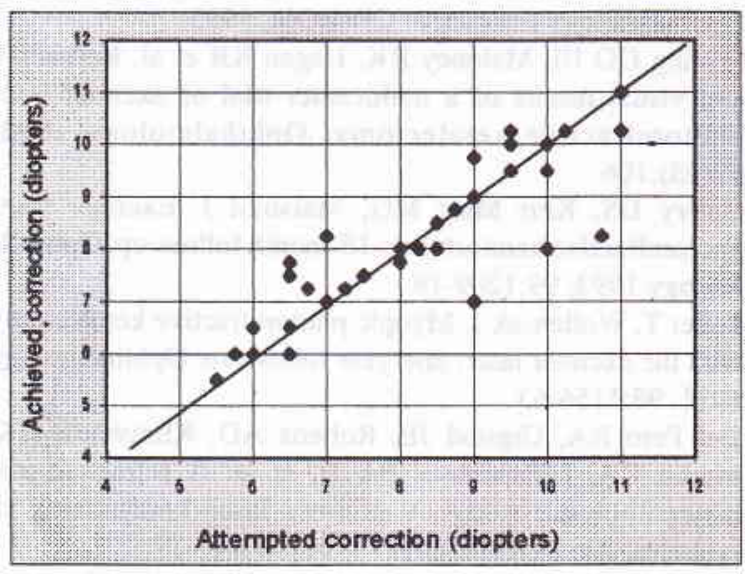

Figure 2. Group B: Attempted versus achieved correction after 6 months

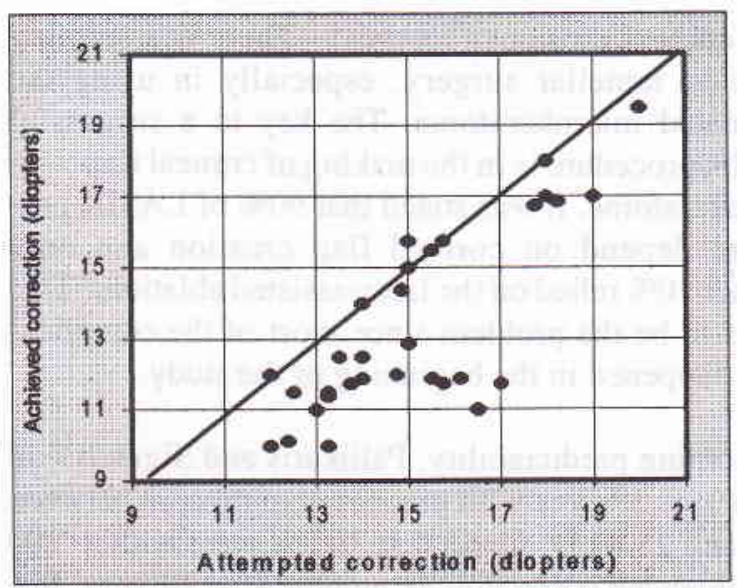

Figure 3. Group C: Attempted versus achieved correction after 6 months

\section{DISCUSSION}

The goal of this study was to determine the safety and efficacy of excimer laser keratomileusis as a treatment to correct myopia.

Corneal clarity is the main factor in evaluating the safety of the procedures. Several studies ${ }^{10-12}$ have found varying degrees of subepithelial haze after PRK. The corneal opacification correlated with the presence of subepithelial activated fibroblasts and the presumed synthesis of new collagen and other components of the extracellular matrix. ${ }^{3}$ Marshall and coworkers ${ }^{9}$ reported that although most cellular activity after PRK stopped at three months postoperatively, the healing process continued for up to 8 months postoperatively. By 8 months, the morphology of the cornea was near normal with the exception that Bowman's membrane was absent and there was still a degree of disorder in the immediate subepithelial stromal fibers. In LASIK, haze occurs in different anatomical location than in PRK. By applying laser energy directly to the stromal bed, LASIK spares Bowman's membrane and the epithelium, thus avoiding the problems associated with deep surface ablation. In this study, all corneas were clear before surgery. The degree of haze after LASIK was minimal in all eyes. This finding indicates that preservation of Bowman's layer may be important in corneal healing.

Complications were found in $6 \%$ of eyes of all groups, although none was vision threatening. The most frequent complication of LASIK procedures is epithelial ingrowth, possibly from debris in the interface. In this study, interstitial debris was found in 8 eyes, second 
after corneal erosions (16 eyes). There is a learning curve to lamellar surgery, especially in using the automated microkeratome. The key to a successful LASIK procedure is in the making of corneal flap with microkeratome. It was stated that $90 \%$ of LASIK procedure depend on corneal flap creation and only another $10 \%$ relied on the laser-assisted ablation. ${ }^{9}$ This seems to be the problem since most of the complications happened in the beginning of the study.

Concerning predictability, Pallikaris and Siganos ${ }^{14}$ in a series of 39 eyes with preoperative myopia between 8.50 and $25.87 \mathrm{D}$, found that $79.2 \%$ were within 2.00 D of intended correction 24 months after surgery. In a series of 88 eyes with mean spherical equivalent -8.24 $D$, Salah et al ${ }^{15}$ found that $72 \%$ had a refraction within 1.00 D 5 months after LASIK. Perez-Santonja et al ${ }^{16}$ found that 6 months after LASIK 72.4\% of eyes in the low myopia group ( -8.00 to $-11.99 \mathrm{D}), 46.0 \%$ in the moderate myopia group $(-12.00$ to $-15.99 \mathrm{D})$, and $50.0 \%$ in the high myopia group (-16.00 to $-20.00 \mathrm{D})$, were within $1.00 \mathrm{D}$ of emmetropia.

In this study, at 6 months after surgery, the achieved correction was within $2.00 \mathrm{D}$ of attempted correction in 44 eyes $(95.65 \%)$ in group A, 43 eyes $(97.73 \%$ ) in group B, and 25 eyes $(78.13 \%)$ in group C. The total number of eyes at 6-month follow-up were 122 eyes.

Refractive results after 6 months in group A showed that there was a tendency toward overcorrection (Figure 1). This is in contrast to refractive results in group $\mathrm{C}$, which showed that most of the cases were undercorrected (Figure 3). These findings may indicate that the laser ablation normogram used in this study (Table 1, Maria Clara's modification) need more adjustment.

The mean postoperative spherical equivalent seems to stabilize early in the postoperative period. The mean regression between the $1^{\text {st }}$ and $6^{\text {th }}$ month was less than I.00 D. Stability of the spherical equivalent with time may have to do with initial site of tissue removal below Bowman's layer in LASIK, which seems to provoke a less intense healing response. However, in view of the relatively short follow-up at the current stage of this study, it is too early to conclude that the stability suggested by the mean refractive results after 6 months postoperatively is predictive of future refractive stability.

Statistical analysis was not done in this study, because the numbers of eyes during follow-up were constantly changing.

\section{CONCLUSION}

The results of this study show that laser in-situ keratomileusis with the 193-nm argon fluoride excimer laser can correct myopia with good accuracy and predictability. Results also tend to suggest stability of refraction. Further investigations should be made to obtain an improved ablation normogram to correct extremely high myopia.

\section{REFERENCES}

1. Trokel SL, Srinivasan R, Braren B. Excimer laser surgery of the comea. Am J Ophthalmol 1983; 96:710-5.

2. Marshal J, Trokel S, Rothery S, Krueger RR. A comparative study of corneal incisions induced by diamond and steel knives and two ultraviolet radiations from an excimer laser. Br J Ophthalmol 1986; 70:482-501.

3. Kerr-Muir MG, Tokel SL, Marshal J, Rothery S. Ultrastructural comparison of conventional surgical and argon fluoride excimer laser keratectomy. Am J Ophthalmol 1987; 103:44853.

4. McDonald MB, Kaufmann HE, Frantz JM, Schofner S, Shofner S, Salmeron B, et al. Excimer laser ablation in a human eye. Arch Ophthalmol 1989;107:641-2.

5. Hamberg-Nyström H, Fagerholm P, Sjöholm C, Tengroth B. Photorefractive keratectomy for 1.5 to 18 diopters of myopia. J Refract Surg 1995; 11:S2261-7.

6. Seiler T, Holschbach A, Derse M, Jean B, Genth U. Complications of myopic photorefractive keratectomy with the excimer laser. Ophthalmology 1994; 101:153-60.

7. Pallikaris IF, Siganos DS. Excimer laser in situ keratomileusis and photorefractive keratectomy for correction of high myopia. J Refract Corneal Surg 1994; 10:498510.

8. Casebeer JC, Slade SG, editors. LASIK, Lamellar refractive surgery: technique, technology and complications. Boston: Chiron Vision, 1996.

9. Slade SG. LASIK and lamellar refractive surgery. Boston: Ophthalmology Interactive CD-ROM, 1995.

10. Waring GO III, Maloney RK, Hagen KB et al. Refractive and visual results of a multicenter trial of excimer laser photorefractive keratectomy. Ophthalmology 1992; 99(9S): 106

11. Gartry DS, Kerr Muir MG, Marshall J. Excimer laser photorefractive keratectomy: 18-month follow-up. Ophthalmology 1992; 99:1209-19

12. Seiler T, Wollensak J. Myopic photorefractive keratectomy with the excimer laser: one-year follow-up. Ophthalmology 1991; 98:1156-63

13. Del Pero RA, Gigstad JE, Roberts AD, Klintworth GK, Martin CA, L'Esperance FA Jr, et al. A refractive and histopathologic study of excimer laser keratectomy in primates. Am J Ophthalmol 1990; 109:419-29

14. Pallikaris IG, Siganos DS. Laser in situ keratomileusis to treat myopia: Early experience. J Cataract Refract Surg 1997; 23:39-49 
15. Salah T, Waring GO III, El-Maghraby A, Moadel K, Grimm SA. Excimer laser in situ keratomileusis under a comeal flap for myopia of 2 to 20 diopters. Am J Ophthalmol 1996; 121:143-155
16. Perez-Santonja JJ, Bellot J, Claramonte $\mathrm{P}$, Ismail MM, Allo JL. Laser in situ keratomileusis to correct high myopia. J Cataract Refract Surg 1997; 23:372-85 